\title{
Pulmonary Complications in Children with Sickle Cell Disease Followed at the Pediatric Department of Gabriel Toure University Hospital
}

\author{
Mohamed E. Cissé*, Abdoul A. Diakité, Adama Dembélé, Belco Maiga, Pierre Togo, \\ Nicole A. Kpakoutou, Oumar Coulibaly, Karamoko Sacko, Tiaria M. Sanogo, Hawa Diall, \\ Fousseyni Traoré, Abdoul K. Doumbia, Djenèba Konaté, Fatoumata L. Diakité, Ibrahim Ahamadou, \\ Lalla N. Sidibé, Amadou Touré, Fatoumata Dicko-Traoré, Boubacar Togo, Mariam Sylla
}

Pediatric Department of Gabriel Toure University Hospital, Bamako, Mali

Email: *cisselmouloud@yahoo.fr

How to cite this paper: Cissé, M.E., Diakité, A.A., Dembélé, A., Maiga, B., Togo, P., Kpakoutou, N.A., Coulibaly, O., Sacko, K., Sanogo, T.M., Diall, H., Traoré, F., Doumbia, A.K., Konaté, D., Diakité, F.L., Ahamadou, I., Sidibé, L.N., Touré, A., DickoTraoré, F., Togo, B. and Sylla, M. (2022) Pulmonary Complications in Children with Sickle Cell Disease Followed at the Pediatric Department of Gabriel Toure University Hospital. Open Journal of Pediatrics, 12, 89-99.

https://doi.org/10.4236/ojped.2022.121011

Received: December 15, 2021

Accepted: January 18, 2022

Published: January 21, 2022

Copyright $\odot 2022$ by author(s) and Scientific Research Publishing Inc. This work is licensed under the Creative Commons Attribution International License (CC BY 4.0).

http://creativecommons.org/licenses/by/4.0/

(c) (i) Open Access

\begin{abstract}
Objective: To study the pulmonary complications of major sickle cell syndromes in children aged 6 months to 15 years followed at the Department of Pediatrics of Gabriel Toure University Hospital. Materials and methods: This was a retrospective study from January $1^{\text {st }}, 2017$ to February 28, 2018 and a prospective study from March 1, 2018 to December 31, 2019, concerning sickle cell disease children followed at the Gabriel Touré University Hospital. All children with sickle cell disease confirmed by hemoglobin electrophoresis, aged 6 months to 15 years with a pulmonary complication and admitted to pediatrics were included. Were not included: 1) Infants and children with sickle cell disease not presenting a pulmonary complication coming only to their routine follow-up. 2) Sickle cell patients over 16 years of age and those whose parents do not consent. 3) Those who have not done electrophoresis. Results: During the study period, we were able to include 45 sickle cell children with a pulmonary complication. The frequency of pulmonary complications was $13.76 \%$, involving homozygotes in $91.11 \%$ of cases. The age group 6 - 10 years predominated with $46.66 \%$ and the sex ratio was 0.45 . Vaso-occlusive crisis was the most frequent reason for consultation with $35.56 \%$. Respiratory distress $(80 \%)$, fever $(66.67 \%)$, crepitus rales $(64.44 \%)$ and chest pain (60\%) were the most frequent clinical signs. The main pulmonary complication was acute chest syndrome with $86.67 \%$. Treatment was based on hydration (91.91\%), analgesics (91.91\%) and antibiotics (73.33\%). Lethality was 4.44\%. Conclusion: Pulmonary complications of sickle cell disease are serious and constitute the main cause of mortality in our context.
\end{abstract}




\section{Keywords}

Sickle Cell Disease, Children, Lungs, Complications

\section{Introduction}

Every year, nearly 300,000 children are born with a major hemoglobin abnormality, including more than 200,000 cases in Africa [1] [2].

In Mali, according to Center of management and research of Sickle cell disease called "Le Centre de Recherche et de Lutte contre la Drépanocytose (CRLD)", there are 5000 to 6000 sickle cell births each year with a prevalence of $12 \%$, including $3 \%$ for the major form [3]. They are subject to complications that can affect all organs, which makes sickle cell disease a disabling disease, with a 5-year probability of hospitalization for painful vaso-occlusive crisis (VOC) of $63 \%$, for acute chest syndrome (ACS) of $45 \%$, and for acute anemia of $30 \%$ [4]. Pulmonary disorders are of particular importance because of their frequency and severity. They represent $20 \%$ to $30 \%$ of the causes of mortality [5]. Recent publications show that asthma represents an unfavorable comorbidity in major sickle cell syndromes (MDS) in children. Its presence increases the risk of occurrence of vaso-occlusive attacks (VOC) and acute chest syndrome (ACS) [6] [7].

The difficulties in the management of pulmonary complications and the absence of previous studies in the pediatric setting in Mali motivated the realization of this work, which aims to study pulmonary complications in children with sickle cell disease followed up in the pediatric department of the Gabriel Toure University Hospital.

\section{Materials and Methods}

Our study took place at the Gabriel Toure University Hospital Center. It was a retrospective study from January 1, 2017 to February 28, 2018 and prospective from March 1, 2018 to December 31, 2019. All children with sickle cell disease confirmed by hemoglobin electrophoresis, aged 6 months to 15 years with a pulmonary complication and admitted to pediatrics were included. Were not included:

- Infants and children with sickle cell disease not presenting a pulmonary complication coming only to their routine follow-up.

- Sickle cell patients over 16 years of age and those whose parents do not consent.

- Those who have not done electrophoresis.

During the study period we were able to include 45 sickle cell children with a pulmonary complication. Sociodemographic, clinical and paraclinical variables were analyzed.

Data collection was carried out by means of a questionnaire form filled in 
from the patients' hospitalization records and the sickle cell disease follow-up booklet. The data collected were entered and analyzed using Microsoft Word 2007 and SPSS version 17.0 software. We used the Chi-square test for the comparison of categorical variables. The value of $p<0.05$ was considered statistically significant. Informed consent was requested and obtained from the parents or caregivers before including the patient. Confidentiality of data was respected during the study. Authorization from the head of the department was obtained for the use of medical records.

\section{Results}

Our study concerned children with sickle cell disease under the age of 16 with a pulmonary complication in the pediatric department of Gabriel Toure University Hospital.

Limits of our study

As any retrospective study presents difficulties, we encountered difficulties related to:

- Missing information in the files;

- The non-feasibility of spirometry in children under 5 years old;

- The unavailability of spirometry inside the hospital and its high cost.

\subsection{Frequency}

From January 01, 2017, to December 31, 2019, we collected 45 records of children who presented a pulmonary complication out of 327 sickle cell children followed at the Department of Pediatrics of the Gabriel Touré University Hospital, i.e. a frequency of $13.76 \%$.

\subsection{Sociodemographic Parameters}

The age range of 6 to 10 years represented $46.66 \%$ and the sex-ratio was 0.45 . (Figure 1 \& Figure 2)

The children were from consanguineous marriages in $22.22 \%$ of cases. The fathers were shopkeepers in $42.22 \%$ of cases and civil servants in $22.22 \%$ of cases while the mothers were housewives in $60 \%$ of cases and civil servants in $26.66 \%$ of cases. Non-educated children represented $55.55 \%$ of the mothers and $40 \%$ of the fathers.

\subsection{Clinical and Paraclinical Parameters}

The children had a history of hospitalization in $53.33 \%$ of cases and a history of chest pain or dyspnea in $24.4 \%$ of cases. The discovery (of sickle cell disease) was made between 6 months and 5 years of age in $64.44 \%$, 40\% of whom had osteoarticular pain (Table 1 and Table 2).

Vaso-occlusive crisis (VOC) represented $35.56 \%$ of the reasons for consultation (Table 3).

On admission, $89 \%$ of the children had fever, $71.11 \%$ had tachypnea, and 
$66.67 \%$ had a pulsed saturation below $95 \%$. The most common clinical signs were respiratory distress $(80 \%)$, crepitus $(64.44 \%)$, of which one third was bilateral, and chest pain (60\%) (Table 4).

Complications were dominated by acute chest syndrome with $86.67 \%$ (Table $5)$.

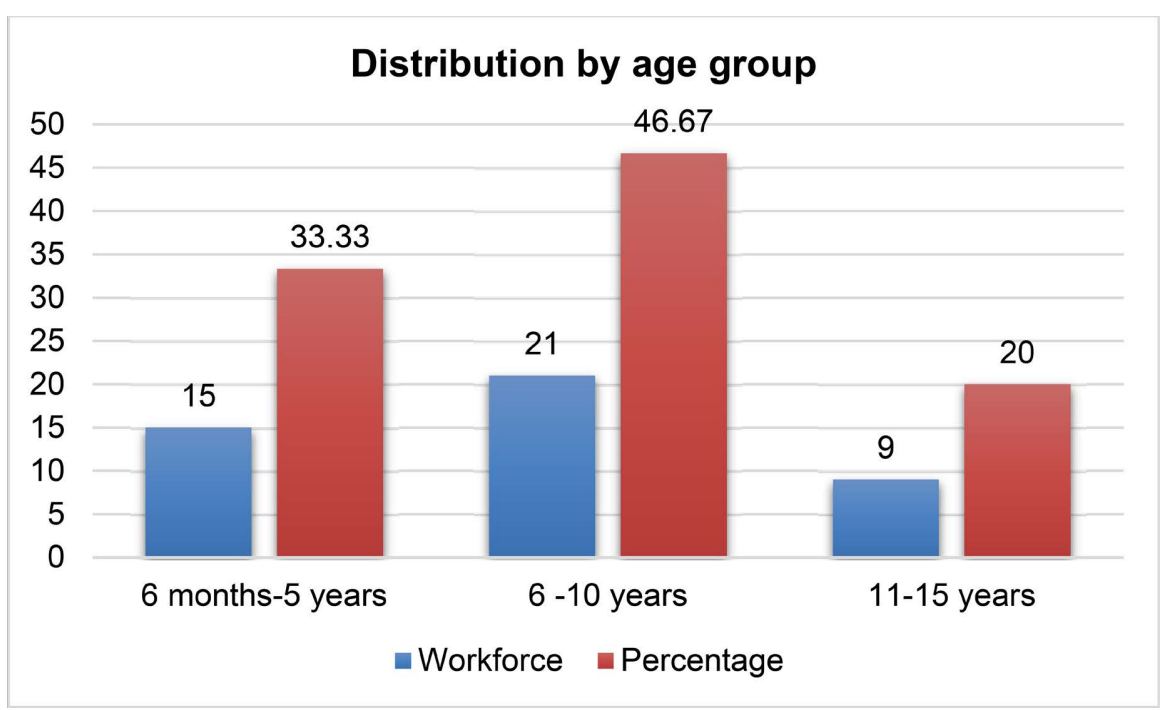

Figure 1. Distribution of patients according to age.

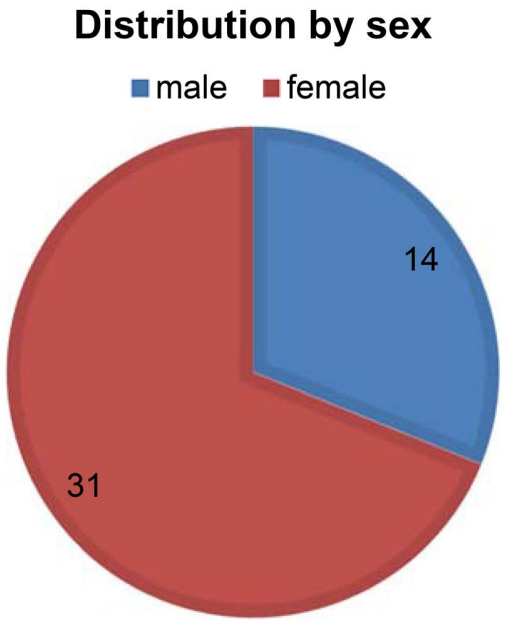

Figure 2. Distribution of patients by sex.

Table 1. Distribution of patients according to the number of previous hospitalizations.

\begin{tabular}{cccc}
\hline Number of previous hospitalizations & Effective & Percentage \\
\hline 1 & 15 & 33.33 \\
2 & 6 & 13.33 \\
3 & 2 & 4.44 \\
$>3$ & 1 & 2.22 \\
Total & 24 & 53.33 \\
\hline
\end{tabular}


Table 2. Distribution of patients according to the circumstance of discovery of sickle cell disease.

\begin{tabular}{ccc}
\hline circumstance of discovery & Effective & Percentage \\
\hline Osteoarticular pain & 18 & 40 \\
Systematic assessment & 12 & 26.66 \\
Anemia & 9 & 20 \\
Hand-foot syndrome & 6 & 13.33 \\
Total & 45 & 100 \\
\hline
\end{tabular}

Table 3. Distribution of patients according to reason for consultation/referal.

\begin{tabular}{ccc}
\hline Reason for consultation/referal & Effective & Percentage \\
\hline vaso-occlusive crisis & 16 & 35.56 \\
Acute thorac syndromes + Pneumonia & 14 & 31.11 \\
Respiratory distress & 8 & 17.78 \\
Anemia & 3 & 6.67 \\
Other* (see below) & 4 & 8.88 \\
Total & 45 & 100 \\
\hline
\end{tabular}

${ }^{\star}$ Other: Convulsion $=2$, coughing + vomiting $=1$, Desaturation $=1$.

Table 4. Distribution of patients according to clinical signs.

\begin{tabular}{ccc}
\hline Clinical Signs & Effective & Percentage \\
\hline Respiratory distress & 36 & 80 \\
Crackling rales & 29 & 64.44 \\
Chest pain & 27 & 60 \\
Mucocutaneous pallor & 24 & 53.33 \\
Matter & 15 & 33.33 \\
Conjunctival jaundice & 13 & 28.89 \\
Hepato-Splenomegaly & 13 & 28.89 \\
Heart murmure & 04 & 8.88 \\
Skin lesions & 02 & 4.44
\end{tabular}

Table 5. Distribution of patients according to the types of pulmonary complications.

\begin{tabular}{ccc}
\hline Pulmonary complications & Effective & Percentage \\
\hline Acute thorac syndromes & 39 & 86.67 \\
Acute thorac syndromes + pulmonary hypertension & 1 & 2.22 \\
Pneumonia & 5 & 11.11 \\
Total & 45 & 100
\end{tabular}


There was hyperleukocytosis in $97.77 \%$ of cases, anemia in $93.33 \%$ of cases and opacity (on radiography) which was bilateral basal in $26.67 \%$ of cases, right basal in $20 \%$ and left basal in $17.78 \%$ of cases. One case of pulmonary hypertension was found on cardiac Doppler ultrasound. Management was based on hydration, taking into account the child's needs and the risk of pulmonary overload (i.e. 1.5 to 2 liters $/ \mathrm{m}^{2} / 24$ hours without exceeding 2 liters/24hours), broad antibiotic therapy active spectrum on intracellular germs and pneumococcus (amoxicillin, amoxi-clavulanic acid and cefotaxime or Ceftriaxone), oxygen therapy to maintain arterial oxygen saturation $>95 \%$. The antibiotic of choice is Amoxicillin in sufficient dose (100 mg/kg/day) due to its good bioavailability. Thus the management focused on hydration (with isotonic solution) in $91 \%$ of cases, level II analgesics in $91 \%$ of cases, antibiotic therapy in $100 \%$ of cases, oxygen therapy in $80 \%$ of cases. Blood products were transfused in $51.31 \%$ of the children, phenotyped red blood cells in $31.31 \%$, non-phenotyped red blood cells in $17.78 \%$ and nonphenotyped whole blood in $2.22 \%$ of children. Incentive spirometry was prescribed in $84.44 \%$ of children and $13.33 \%$ of children were put on hydroxycarbamide. We recorded two deaths, i.e. a mortality rate of $4.44 \%$.

There are significant relationship between the type of hemoglobin and the reasons for consultation or referral $(\mathrm{P}=0.02)$ on the one hand and between the type of hemoglobin and the type of complication $(\mathrm{P}=0.001)$ on the other (Table 6 and Table 7).

Table 6. Distribution of patients according to the reason for consultation and the type of hemoglobin.

\begin{tabular}{ccccc}
\hline \multirow{2}{*}{$\begin{array}{c}\text { Reason for } \\
\text { consultation/Reference }\end{array}$} & \multicolumn{2}{c}{ Type of hemoglobin } & \multirow{2}{*}{ Total } \\
\cline { 2 - 5 } $\boldsymbol{S}^{\circ}$ thalassemia & SC & SS & \\
\hline Anemia & 0 & 0 & 3 & 3 \\
CVO & 1 & 1 & 21 & 23 \\
Pulmonary complications & 1 & 1 & 17 & 19 \\
Total & 2 & 2 & 41 & 45 \\
\hline
\end{tabular}

$\mathrm{X}^{2}: \mathrm{P}=0.02$

Table 7. Distribution of patients according to the type of pulmonary complication and the type of hemoglobin.

\begin{tabular}{ccccc}
\hline \multirow{2}{*}{$\begin{array}{c}\text { Type of } \\
\text { hemoglobin }\end{array}$} & $\begin{array}{c}\text { Acute thorac } \\
\text { syndromes }\end{array}$ & Pneumonia & $\begin{array}{c}\text { Acute thorac syndromes+ } \\
\text { pulmonary hypertension }\end{array}$ & Total \\
\hline SS & 36 & 4 & 1 & 41 \\
SC & 1 & 1 & 0 & 2 \\
S $\beta^{\circ}$ thalassémie & 2 & 0 & 0 & 2 \\
Total & 39 & 5 & 1 & 45 \\
\hline
\end{tabular}

$\mathrm{X}^{2}: \mathrm{P}=0.001$ 


\section{Discussion}

\section{Frequency}

From January 1, 2017 to December 31, 2019, we collected 45 records of sickle cell children with pulmonary complications out of the 327 sickle cell children followed at the sickle cell unit of the pediatrics department of the Gabriel Touré University Hospital, i.e. a frequency of $13.76 \%$.

\section{Sociodemographic parameters}

The age group of 6 to 10 years was the most represented with $46.66 \%$, the same observation was made by Berthold S et al. [8] who, in a study of respiratory complications in children in Brussels, found $39.7 \%$.

The average age was 7.4 with extremes ranging from 14 months to 15 years. These data are comparable to those of Berthold $\mathrm{S}$ et al. [8] who found a mean age of 8 years with extremes ranging from 5.6 to 10 years. The female sex was the most represented, with a sex ratio of 0.45 . Our results are different from those of Berthold S et al. [8] who respectively found a sex ratio of 2.12. For the moment, the predominance of one gender cannot be explained. The occupation of the fathers was dominated by traders (42.22\%), followed by civil servants with $22.22 \%$. Diakité AA et al. [9] also observed a predominance of traders with $35.7 \%$ followed by civil servants with $25.7 \%$. This result was due to the fact that civil servants and shopkeepers have an acceptable standard of living that allows them to bring their children to consultations. The majority of mothers (60\%) were housewives; other authors in Mali, such as Diakité AA et al [9], found this predominance of housewives with $80 \%$. This result could be explained by the low schooling rate of girls in Mali. We observed 22.22\% of children born of a consanguineous marriage. This could be explained by the practice of endogamy in Mali. Our results are lower than those of Belala A et al. [10] who found consanguinity in $45 \%$ of cases.

\section{Clinical and paraclinical parameters}

The most common age of discovery was 6 months to 5 years $(64.44 \%)$. This could be explained by the high susceptibility to infections at this age and the appearance of the first symptoms in relation to the disappearance of fetal hemoglobin. The most frequent circumstances of discovery were osteoarticular pain with $40 \%$. Douamba S et al [11] found that the first circumstance of discovery was infections with $24.8 \%$. More than half of the children (53.33\%) had a history of hospitalization. Infections were the most noted reason for hospitalization with $34.21 \%$. Our results are superior to those of Bertholdt et al. [8] and Douamba S et al. [11] who found respectively $8 \%$ and $21.8 \%$ of previous hospitalization. This repetition of hospitalization could be explained by the vulnerability of sickle cell children. Chest pain/dyspnea was found in $24.4 \%$ of children. The main reason for consultation was vaso-occlusive crisis (35.56\%), the same observation was made by Bertholdt S [8] who had $40 \%$ vaso-occlusive crisis as the main reason for consultation. This could be explained by the fact that the vaso-occlusive crisis represents a triggering factor of a pulmonary complication (acute thoracic syn- 
drome) or contemporary with it. More than half of the children (66.67\%) had a fever on entry. This result is lower than that of Douamba S et al. [11] who had $95.5 \%$. This frequency of fever would be related to the extreme susceptibility of sickle cell patients to infection. More than half $(66.67 \%)$ of the children had a saturation of less than $95 \%$. Bertholdt $S$ et al. [8] found $50 \%$ of patients with saturation $<95 \%$. The hypoventilation observed in acute chest syndrome would be the cause of the poor oxygen saturation. In this study, clinical signs were dominated by respiratory distress $(80 \%)$, followed by crepitus and chest pain with $64.44 \%$ and $60 \%$ respectively. Bertholdt $S$ et al. [8] found $58.33 \%$ chest pain and $50 \%$ respiratory distress. This could be explained by the symptomatology of acute chest syndrome which is made of respiratory distress and chest pain. Almost three quarters $(71.11 \%)$ of our patients had presented with intercostal pulling and $60 \%$ presented with subcostal pulling. This was a respiratory struggle observed in young children in respiratory distress with the presence of bilateral crackles in $33.33 \%$ of cases. The crackles were bilateral in $33.33 \%$ of our patients, located on the left in $17.78 \%$ and on the right in $13.33 \%$. The complications observed were acute chest syndrome (86.67\%), pneumonia (11.11\%) and pulmonary arterial hypertension + acute chest syndrome (2.22\%). These results are superposable to those of Bertholdt $S$ et al. [8] who found acute chest syndrome as the main complication with $75 \%$.

In our study the SS form predominated with $91.11 \%$ followed by the SC and $\mathrm{S} \beta^{\circ}$ thalassemia forms with $4.44 \%$ each. These results are comparable to those of Bertholdt S et al. [8] who had found a predominance of SS with $95.45 \%$. This is due to the high prevalence of SS in the Sahelian zone in general and to the predominance of the SS form among the children followed up at the sickle cell disease unit of the Gabriel Touré University Hospital. Hyperleukocytosis was noted in $97.77 \%$ of our patients, with an average of $31,856 / \mathrm{mm}^{3}$ leukocytes and extremes ranging from 11,500 to $78,300 / \mathrm{mm}^{3}$ Douamba S et al. [11] found that $84.9 \%$ of patients had hyperleukocytosis with a mean leukocyte count of $22,945 / \mathrm{mm}^{3}$ with extremes ranging from 6400 to $78,600 / \mathrm{mm}^{3}$. This could be explained by the presence of hyperleukocytosis in sickle cell patients without any infection and the extreme susceptibility of these children to infection. A hemoglobin level of less than $10 \mathrm{~g} / \mathrm{dl}$ was found in $93.33 \%$ of the patients with an average of $6.53 \mathrm{~g} / \mathrm{dl}$ and extremes ranging from $2.6 \mathrm{~g} / \mathrm{dl}$ to $10.8 \mathrm{~g} / \mathrm{dl}$. Our results are comparable to those of Douamba $S$ et al. [11] who in their study in Burkina Faso found a mean hemoglobin level of $6.7 \mathrm{~g} / \mathrm{dl}$ with extremes ranging from $2.5 \mathrm{~g} / \mathrm{dl}$ to $10 \mathrm{~g} / \mathrm{dl}$, but lower than those of Bertholdt $\mathrm{S}$ et al. [8] who found a mean hemoglobin level of $8.3 \mathrm{~g} / \mathrm{dl}$ with extremes ranging from $7.3 \mathrm{~g} / \mathrm{dl}$ to $9.5 \mathrm{~g} / \mathrm{dl}$. Indeed, anemia is constant in sickle cell patients due to chronic hemolysis and can worsen in acute situations. Of $97.78 \%$ of patients who had a thick blood drop, about half (44.44\%) were positive. In the study by Douamba S [11], it was done in all patients with $12.8 \%$ of positive results. Mali being a malaria endemic area, malaria remains one of the triggers of the attacks. Chest X-ray was abnormal in $64.44 \%$ 
of cases $(n=29)$. This result is lower than that of Douamba $S$ [11] who found $76.5 \%(\mathrm{n}=50)$ of abnormalities on the chest X-ray. This difference can be explained by the delay of the imaging compared to the clinic. Repeat radiography was often necessary, but insufficient financial resources limit the performance of chest x-rays. Cardiac Doppler ultrasound was abnormal in two of the six children who had the examination. In the study by Douamba $S$ [11], cardiac ultrasound was performed in 36 patients with $73.5 \%(n=26)$ of anomalies.

\section{Management and outcome}

Hydration with Ringer Lactate (RL) and $0.9 \%$ saline (SS) was used to reduce pain in $91.11 \%(n=41)$ of patients. Our results are superior to those of Diagne I et al. [12] who found $66.6 \%$ of cases of hyperhydration. These high rates of hyperhydration can be explained by the importance of hydration in the management of pain in sickle cell patients. A level I and II analgesic had been used in $91.11 \%$ of patients. Diagne I et al. [12] found that $66.6 \%$ of the patients had received level I and II analgesics during their vaso-occlusive crises. While Bertholdt S [8] had used morphine in $33.33 \%$ of these patients for pain relief. This could be explained by the intensity of pain in the sickle cell patient. In our context the availability and handling of morphine explains the use of levels I and II. Nearly three quarters of our patients (73.33\%) received treatment with third generation cephalosporins, followed by vancomycin (55.56\%), gentamycin and the combination of amoxicillin and clavulanic acid in $51.11 \%(\mathrm{n}=23)$ each. Our results are close to those of Douamba S [11] who used ceftriaxone (64.6\%), gentamicin (48.9\%), amoxicillin-clavulanic acid combination (16\%). Antibiotics were combined in $86.66 \%(n=39)$ of cases. This same observation was made by Douamba S [11] in $71.4 \%$ of his patients. The majority of our patients $(68.89 \%)$ were put on oxygen. Our results are superior to those of Bertholdt $S$ et al. [8] who used oxygen therapy in $50 \%$ of their patients. The oxygen flow rate was greater than or equal to 31 in $44.44 \%$ of cases. Weaning occurred between $3-4$ days in $33.33 \%$ of cases $(n=15)$. This oxygen use is explained by desaturation which is frequently observed in pulmonary complications of sickle cell disease. Non-phenotyped packed red blood cells were transfused in $31.31 \%$ of patients. Bertholdt $S$ et al. [8] had transfused $44 \%$ of their patients with packed red blood cells. Ideally, phenotyped red blood cells should be transfused, but the availability of phenotyped blood in emergency situations is lacking in our context. Incentive spirometry was advised in $84.44 \%$ of patients. Ideally, spirometry should have been performed in all patients over 5 years of age, but the lack of financial means, the non-availability and the high cost of this examination in the hospital were lacking in our study. Half of our patients $(51.11 \%)$ were relieved of their attacks between 6 and 10 days. The average length of hospitalization was 7.5 days with extremes ranging from 2 to 30 days. Our average length of hospitalization is comparable to that of Bertholdt $S$ et al. [8] who found 7 days with extremes ranging from 4.5 to 11 days. We recorded two deaths $(4.44 \%)$ all in the context of acute chest syndrome. This result is lower than that of Douamba S 
[11] who had in Burkina Faso 7.5\% $(\mathrm{n}=10)$ of cases of death in major sickle cell syndromes and associated infections in children.

There are significant relationship between the type of hemoglobin and the reasons for consultation or referral $(\mathrm{P}=0.02)$ on the one hand and between the type of hemoglobin and the type of complication $(\mathrm{P}=0.001)$ on the other. These relationships are linked to the specifics of each form of sickle cell disease, which is why there has been more reference due to anemia in the homozygous form.

\section{Conclusions}

Sickle cell disease is a source of pulmonary complications. In our study, we noted $13.76 \%$ of pulmonary complications in the children followed. They are determined by the acute thoracic syndrome $(87.67 \%)$ hence the need to repeat the chest X-ray for follow-up. His mortality rate was $4.44 \%(\mathrm{n}=2)$.

At the end of our study, we recommend to:

- Make spirometry accessible at a lower cost;

- Strengthen the training of sickle cell specialists;

- Provide the imaging in pediatrics department with a mobile $\mathrm{x}$-ray machine.

\section{Conflicts of Interest}

The authors declare no conflicts of interest regarding the publication of this paper.

\section{References}

[1] Piel, F.B., Steinberg, M.H. and Rees, D.C. (2017) Sickle Cell Disease. New England Journal of Medicine, 376, 1561-1573. https://doi.org/10.1056/NEJMra1510865

[2] Pleasants, S. (2014) Epidemiology: A Moving Target. Nature, 515, S2-S3. https://doi.org/10.1038/515S2a

[3] Diallo, D.A. (2008) Sickle Cell Disease in Africa: Current Situation and Strategies for Improving the Quality and Duration of Survival. Bulletin de l'Académie nationale de médecine, 192, 1361-1372.

[4] Pondarré, C., Guitton, C., Hau, I., Ngo, J. and Thuret, I. (2018) Prise en Charge Pratique des Complications Aigues de la Drépanocytose Chez l'enfant. Perfectionnement en Pédiatrie, 1, 237-248. https://doi.org/10.1016/j.perped.2018.10.007

[5] Lionnet, F., Arlet, J.B., Bartolucci, P., Habibi, A., Ribeil, J.A. and Stankovic, K. (2009) Recommandations pratiques de prise en charge de la drépanocytose de l'adulte. $L a$ Revue de Médecine Interne, 30, S162-S223. https://doi.org/10.1016/j.revmed.2009.07.001

[6] Bernaudin, F., Strunk, R.C., Kamdem, A., Arnaud, C., An, P., Torres, M. and al. (2008) Asthma Is Associated with Acuted Chest Syndrome, But Not with an Increased Rate of Hospitalization for Pain among Children in France with Sickle Cell Anemia: A Retrospective Cohort Study. Haematologica, 93, 1917-1918.

https://doi.org/10.3324/haematol.13090

[7] Boyd, J.H., Macklin, E.A., Strunk, R.C. and DeBaun, M.R. (2006) Asthma Is Associated with Acute Chest Syndrome and Pain in Children with Sickle Cell Anemia. Blood, 108, 2923-2927. https://doi.org/10.1182/blood-2006-01-011072 
[8] Bertholdt, S., Le, P.Q., Heijmans, C., Huybrechts, S., Dedeken, L., Devalck, C., et al. (2012) Les Complications Respiratoires Chez les Enfants: Le Syndrome Thoracique Aigu. Revue Médicale de Bruxelles, 33, 138-144.

[9] Diakité, A.A., Coulibaly, Y., Dicko, T.F., Traore, B., Togo, B., Dembele, A., et al. (2009) Prise en Charge de la Douleur au Cours de la Drépanocytose Selon les Critères de l'OMS en Milieu Pédiatrique. Mali Medical, 24, 25-27.

[10] Belala, A., Marc, I., Hajji, A., Belghyti, D. and El Kharrim, K. (2016) La Drépanocytose Chez les Enfants Hospitaliers au Service de Pédiatrie (Chr el Idriss de Kenitra, Maroc): à Propos de 53 cas. European Scientific Journal, 12, 201-210. https://doi.org/10.19044/esj.2016.v12n12p201

[11] Douamba, S., Nagalo, K., Tamini, L., Traore, I., Kam, M., Koueta, F., et al. (2017) Syndromes Drépanocytaires Majeurs et Infections Associées Chez l'enfant au Burkina Faso. The Pan African Medical Journal, 26, 7. https://doi.org/10.11604/pamj.2017.26.7.9971

[12] Diagne, I., Ndiaye, O., Moreira, H., Sygnate-Sy, H., Camara, B., Diouf, S., et al. (2000) Les Syndromes Drépanocytaires Majeurs en Pédiatrie à Dakar (Sénégal). Archives de Pédiatrie, 7, 16-24. https://doi.org/10.1016/S0929-693X(00)88912-5 